\title{
KONSTRUKSI BERFIKIR KRITIS MELALUI PENGENALAN FUNGSI JAM DAN KONSEP WAKTU PADA ANAK USIA DINI
}

\author{
Wahju Dyah Laksmi Wardhani', Dewi Khoirotus Sadiyah², \\ Universitas Muhammadiyah Jember \\ TK Yasmin Jember
}

\author{
Email : dyahlaksmi_paud@ unmuhjember.ac.id ${ }^{1}$, \\ dewikhoirotus.sadiyah@gmail.com²
}

\begin{abstract}
Abstrak
Kajian ini merupakan penelitian tindakan kelas pada anak kelompok usia 5 - 6 tahun di Sekolah Laboratorium Taman Kanak-Kanak Yasmin Jember, yang bertujuan untuk mengenalkan fungsi jam dan konsep waktu. Pengenalan tentang jam sudah sering dilakukan di TK Yasmin, yang dikaitkan dengan pengenalan lambang bilangan yang ada pada jam. Sedangkan konsep waktu dikenalkan pada anak berkaitan dengan kegiatan sehari-hari yang dilakukan anak. Namun pengenalan fungsi angka, fungsi jarum jam sebagai penunjuk lama atau kapan keberlangsungan suatu kegiatan dilakukan, yang dikenal sebagai waktu, seringkali dianggap tidak penting untuk dikenalkan pada anak. Mengenalkan makna waktu mengkonstrak berpikir kritis anak untuk melakukan regulasi memahami sikap, pengetan dan keterampilan agar belajar memahami pentingnya pelaksanaan suatu kegiatan dengan batasan waktu tertentu. Kajian ini dianalisis secara naratif interpretative berbasis teori untuk memahami kompetensi anak dalam mengkonstrak pengetahuan baru dalam bentuk kreatif.
\end{abstract}

Kata kunci: fungsi jam, konsep waktu, berpikir kritis

\begin{abstract}
This study is a class action research aims to introduce the concept of time for young children. Introduction about the hours it has often been done in the kindergarten Yasmin, which is associated with the introduction of existing numbers had taken on the clock or a watch. While the concept of time usually introduced by regarding to everyday activities that kids do. However, the introduction of a number of functions, the clock function as the length pointer for the activity or when the existence of an activity is performed, which is known as time, often considered unimportant for children. The aim of the study is to introduce the meaning of time concept as a critical thinking that helped children to understand about attitude, knowledge and skills in order to regulate the importance of the time limit implementation for their activity in daily life.
\end{abstract}

Keywords: clock function, concept of time, critical thinking

PENDAHULUAN

Pengenalan fungsi jam dan konsep waktu membantu anak mengembangkan kemampuan berpikir kritis tentang orientasi waktu, dengan membiasakan pada kebiasaan-kebiasaan 
rutin, seperti jam masuk sekolah jam 8 pagi, jam pulang sekolah jam 11 siang atau waktu-waktu sholat. Seiring dengan berkembangnya pengetahuan anak tentang waktu, anak juga belajar memahami konsekuensi pembatasan lamanya suatu kegiatan yang dilakukan. Melalui belajar membaca angka, anak belajar membuat konkrit konsep waktu yang abstrak, dalam wujud jam. Saat anak belajar mengenal waktu anak belajar tentang adanya batasan atau tentang lamanya suatu kegiatan berlangsung. Hal ini akan membuat anak untuk belajar mengatur diri sendiri dalam mendisiplinkan diri. (Hildebrand. 1986;250).

Ada dua tipe konsep waktu, yaitu kapan terjadi suatu kejadian dan lamanya suatu kegiatan. Kapan terjadinya suatu kejadian dikenal sebagai sekuen atau urutan dengan pola tertentu seperti bangun tidur, terus mandi, lalu makan pagi dan pergi sekolah. Sedangkan lamanya suatu waktu berkaitan dengan fungsi jam yang menunjukkan lamanya suatu kegiatan berlangsung.

Konsep waktu yang dipelajari anak berkaitan dengan pengalaman yang dialami anak dalam kehidupan yang dikenal sebagai personal experience, berkaitan dengan kapan terjadinya suatu kejadian seperti masa lalu, masa sekarang atau masa depan. Anak dapat membuat pernyataan saat aku masih bayi, tadi malam, waktu liburan dsb. Konsep waktu kedua berkaitan dengan istilah kegiatan sosial, yaitu kegiatan sehari-hari yang bersifat rutin. Konsep ini lebih mudah dipahami karena bisa terjadi secara berurutan dan dapat diprediksikan. Konsep ketiga berkaitan dengan waktu budaya/kultural, yang ditunjukkan oleh fungsi jam atau kalender. Anak dapat belajar tentang istilah menit, detik, jam serta dapat belajar mengetahui kapan atau berapa lama kejadian berlangsung. (Charlesworth. 1990. 234).

Kajian dalam penelitian ini untuk menjawab masalah tentang bagaimana konstruksi pengenalan fungsi jam dan konsep waktu pada anak usia dini kelompok B. Pengenalan konsep waktu berhubungan dengan pembelajaran Sains dan matematika. Pengenalan tentang waktu dengan menggunakan media jam sudah biasa dilakukan oleh guru untuk mengenalkan konsep kegiatan harian atau kegiatan rutin yang biasa dilakukan oleh anak.

Guru PAUD biasanya mengenalkan angka-angka pada jam yang berhubungan dengan waktu yang dijalani anak seperti jam masuk sekolah, jam pulang sekolah, jam istirahat. Sedangkan pengenalan waktu biasanya berhubungan pernyataan verbal/lisan terkait dengan kejadian atau kondisi tertentu, atau mengidentifikasi aktivitas yang dikenal anak. Misalnya, waktu sholat, waktu bangun tidur, waktu tidur, waktu belajar, saat liburan, saat masuk sekolah atau saat di rumah. Waktu juga untuk menunjuk perubahan masa seperti pagi, siang, malam, kemarin, hari ini, atau besok.

Kajian tentang konsep waktu dalam kontek berbahasa anak usia dini 
dikaji oleh Zhang dan Hudson (2018) tentang tata kalimat yang menggunakan keterangan waktu yesterday dan tomorrow. Pentingnya mengkonstrak pemahaman anak tentang waktu dengan mengenalkan adanya pembatasan waktu dalam pengerjaan tugas dikaji oleh Cester, Mioni, Cornoldi (2017). Kajian yang sejenis dengan melatih anak untuk belajar mengukur waktu penyelesaian tugas matematika dilakukan oleh Congdon, Kwon dan Levine (2018).

Waktu merupakan suatu konsep yang abstrak dan memerlukan kemampuan berpikir tingkat tinggi. Namun bukan tidak mungkin diajarkan pada anak usia dini. Membelajarkan konsep waktu pada anak usia dini pada tataran yang lebih tinggi dari hanya mengenal konsep waktu yang dihubungkan dengan kegiatan rutin atau situasi tertentu yang dialami anak atau membaca angka jam, merupakan suatu upaya mengajarkan anak untuk berpikir kritis. Hal ini penting karena melalui kegiatan tersebut anak akan memiliki dasar sikap dan pengetahuan yang akan membantunya untuk mengkonstrak wacana baru secara lebih kreatif tindakan yang dilakukan. Tindakan yang diharapkan muncul dari pemahaman anak tentang waktu misalnya berkaitan dengan melatih disiplin anak dalam kegiatan tertentu seperti waktu bangun dan tidur lebih awal, menjalani ibadah, mengontrol waktu main atau aktivitas yang menuntut adanya pembatasan waktu yang harus dipatuhi anak. Pengenalan akan limitasi waktu juga diperlukan agar anak mampu melatih kemadirian dan tanggung jawabnya, sebagai proses regulasi diri yang memunculkan keterampilan tindak yang lebih terkontrol oleh anak sendiri.

Sebagai upaya menjembatani pembelajaran konsep waktu yang cenderung abstrak, guru dapat menggunakan media-media konkrit yang mudah dimanipulasi anak. Penggunaan jam baik asli maupun bukan dapat membantu anak belajar tentang kebermaknaan angka yang ada dalam jam. Namun agak sulit menggunakan jam untuk mengenalkan anak akan adanya limitasi waktu atau kontrol waktu atas pelaksanaan kegiatan yang akan dilakukan. Misalnya mengenalkan anak bahwa pengerjaan suatu tugas tidak boleh lebih dari 10 menit atau pada jam tertentu anak harus menghentikan kegiatannya untuk berganti kegiatan yang lain. Diperlukan alat bantu yang lebih canggih seperti alarm, stopwatch atau timer untuk membantu konstruksi pengalaman konkrit pada anak. Dengan menggunakan alat-alat tersebut anak belajar mengatur ritme penyelesaian tugas. Terbentuk pula kesadaran akan sikap lebih disiplin, tanggung jawab serta kemandirian anak untuk berupaya memenuhi kontrol waktu tersebut.

Penggunaan media pembelajaran berbasis teknologi merupakan suatu hal yang dipastikan dapat membawa dampak pada peningkatan pemahaman peserta didik. Kajian yang dilakukan oleh Oliemat, Ihmeideh, Al-Khawaldeh (2018) dan Volk , Coti, Zajc, Starci 
(2017) menunjukkan bahwa media berbasis teknologi membantu siswa berhasil dalam capaian pembelajaran yang lebih bagus, baik dalam sikap, pengetahuan maupun tindakan. Pengenalan konsep waktu untuk anak usia dini pada dasarnya diarahkan agar anak memiliki konstrak sikap, pengetahuan maupun tindakan dalam melakukan kegiatan dengan memperhatikan kontrol waktu. Kemampuan anak membangun sikap, pengetahuan dan tindakan secara kritis akan melatih anak untuk kreatif, saat berada pada rentang waktu tertentu dengan tugas tertentu. Karenanya, anak harus belajar dengan media yang lebih canggih dan konkrit untuk memahami adanya kontrol waktu. Disinilah peran dari media seperti alarm, handphone (HP), stopwatch atau timer diperlukan.

$\begin{array}{ccc}\text { Upaya-upaya } & \text { inilah yang } \\ \text { dilaksanakan pada } & \text { kajian dalam }\end{array}$
kegiatan penugasan dosen di sekolah. Sebagai sekolah laboratorium program studi PGPAUD Universitas Muhammadiyah Jember, anak-anak yang duduk sebagai peserta didik kelompok B rata-rata sudah mengenal angka dan mengerti tentang waktuwaktu rutinitas baik di rumah maupun di sekolah. Temuan saat pra siklus menunjukkan bahwa pemahaman tentang waktu dan jam sebatas pada pengenalan angka yang ditunjukkan oleh jam dan waktu dalam arti verbal saja. Artinya anak bisa menyebutkan jam berapa mereka masuk sekolah, jam berapa pulang sekolah, kapan waktu sholat subuh atau kapan waktu sholat maghrib. Anak akan menyebut jam delapan dan menunjukkan angka delapan untuk menyebut waktu masuk sekolah. Atau anak akan menyebutkan waktu pagi usai bangun tidur sebagai waktu sholat subuh atau anak akan mengatakan waktu sholat maghrib saat sudah malam.

Dengan dasar pengetahuan dan pemahaman tersebut akan menjadi mudah untuk meningkatkan kemampuan anak dalam memahami konsep waktu dengan menggunakan jam sebagai alat kontrol. Hal ini perlu dilakukan karena sebagai sekolah laboratorium, TK Yasmin dan guruguru di lembaga tersebut memiliki kewajiban untuk menyelenggarakan standar pendidikan yang sedikit lebih tinggi daripada sekolah di sekitarnya.

Keterlibatan dosen prodi PGPAUD dalam bentuk penelitian dan pengabdian menjadikan upaya ini sebagai koridor mengkonstrak pemahaman guru pada pengetahuan perkembangan pendidikan yang lebih komprehensif bagi konstruksi pendidikan dalam prinsip Revolusi Industri 4.0, dengan lebih melatih kemampuan kreatif, berpikir kritis dan komunikasi pada anak usia dini.

\section{METODE PENELITIAN}

Penelitian dilaksanakan sebagai penelitian tindakan kelas yang mengacu pada model yang dikembangkan oleh Hatch, yaitu penelitian tindakan (action research) untuk pendidikan anak usia dini yang bertujuan sebagai upaya untuk memahami setting pembelajaran di 
PAUD, perilaku anak dan performa guru dalam penyiapan perangkat pembelajaran. Menurut Hatch (2002;96), fokus dari penelitian tindakan kelas memiliki kekhasan yang hasilnya tidak begitu saja dapat diterapkan dalam setting penelitian yang berbeda. Jenis penelitian tindakan ini adalah penelitian kualitatif, dengan teknik analisis naratif-interpretatif. Tujuan penelitian tindakan ini untuk menyelesaikan masalah yang dialami dalam proses pembelajaran serta menemukan data bahan kajian yang dapat digunakan guru untuk memperbaiki perencanaan, pelaksanaan dan evaluasi pembelajarannya dalam konstruksi pengenalan fungsi jam dan konsep waktu untuk anak kelompok B.

Subyek dalam penelitian ini adalah 18 anak yang menjadi siswa di Kelompok B Merapi pada TK Yasmin Jember. TK Yasmin merupakan bagian dari Sekolah Laboratorium PAUD Yasmin, yang dibawah pengelolaan Program Studi PG PAUD Universitas Muhammadiyah Jember. Penelitian dilaksanakan pada awal September hingga 25 Oktober 2018. Data dikumpulkan melalui kegiatan pembelajaran partisipatif, yang mana dosen sebagai peneliti sekaligus bertindak sebagai pelaksana pembelajaran, berkolaborasi dengan guru kelas yang bertindak sebagai pengamat.

Teknik pengumpulan data menggunakan observasi, dokumentasi dan kajian kolaboratif antara guru dan dosen. Observasi dilakukan oleh guru pengamat selama kegiatan pembelajaran berlangsung untuk memperoleh datadata kelebihan dan kendala dalam proses pembelajaran, respon siswa, maupun hasil evaluasi siswa atas pembelajaran yang sudah diikuti. Dokumentasi dilaksanakan dengan mengabadikan reaksi dan respon anak saat proses belajar melalui foto. Dokumentasi juga diperoleh dari portofolio hasil unjuk kerja anak selama siklus berlangsung dan jurnal evaluasi pembelajaran yang merefleksi kegiatan pembelajaran yang sudah dilakukan. Data yang dikoleksi adalah data kualitatif yang diperoleh selama proses pembelajaran dan tes dalam bentuk lembar kerja peserta didik (LKPD) yang juga dikaji dengan membandingkan perkembangan anak antara pre siklus dan pada tiap siklus.

Teknik analisis naratif interpretatif agar pendiskripsian respon siswa maupun tindakan pendidik dapat dipahami lebih akurat. Hal yang sama digunakan untuk mendeskripsikan hasil refleksi terhadap keberhasilan maupun kendala yang muncul dalam proses pembelajaran.

\section{HASIL DAN PEMBAHASAN}

Pengkajian tentang fungsi jam dan konsep waktu pada anak usia dini dirancang dalam dua siklus setelah sebelumnya dilakukan tahap pra siklus untuk mendapatkan data kondisi pengetahuan, sikap dan keterampilan anak terkait dengan fungsi jam dan konsep waktu. Data untuk refleksi 
menggunakan indikator ukur terkait dengan perencanaan, pelaksanaan, observasi dan refleksi. Tahapan tersebut bertujuan mendeskripsikan tentang proses pembelajaran yang sudah dilaksanakan.

\section{A. Perencanaan}

Setelah mengamati proses pembelajaran di tahap pra siklus, maka dosen yang bertugas bersama guru memetakan permasalahan yang ada di kelompok Merapi terkait dengan anakanak yang belum mengetahui hubungan fungsi jam dengan konsep waktu. Kemudian bersama merancang 1)pelaksanaan pretest; 2) merancang kegiatan pembelajaran pada siklus 1 dalam beberapa kali pertemuan. Pada tahap pretest ini, ingin diketahui apakah anak-anak di kelompok Merapi telah mengetahui fungsi jam dan hubungan konsep jam dengan konsep waktu. Hasil dari pretest diketahui sebagian besar anak telah mengenal dan dapat menyebutkan lambang bilangan berupa angka-angka pada jam. Anak-anak juga dapat menyebutkan konsep waktu untuk kegiatan yang mereka lakukan seharihari seperti waktu sholat subuh saat pagi hari, sholat maghrib waktu malam hari, sholat dhuha dan sholat dhuhur waktu siang. Anak juga dapat membedakan waktu pagi, siang dan malam.

Setiap anak antusias menyebutkan waktu-waktu seperti jam masuk sekolah, jam pulang sekolah, menyebutkan bangun pagi. Meski demikian saat ditanyakan apakah anak sekolah pada jam 8 pagi atau jam 8 malam, sebagian besar anak bingung untuk menjawab. Demikian juga saat ditanyakan apakah jam 11 siang saat usai belajar artinya jam 11 malam, ada anak yang berpendapat iya jam sebelas malam tetapi ada anak yang membantah waktu selesai belajar itu jam 11 siang.

Pada kegiatan merancang pembelajaran, bersama disepakati bahwa kompetensi dasar yang digunakan, pertama, mengetahui cara memecahkan masalah sehari-hari dan berperilaku kreatif. Kedua, kompetensi dasar menyelesaikan masalah seharihari secara kreatif. Pada siklus 1 kegiatan difokuskan untuk mengenalkan anak mengetahui cara memecahkan masalah sehari-hari dan berperilaku kreatif melalui mengenal fungsi jam dan konsep waktu. Kegiatan lebih fokus pada membangun regulasi diri anak untuk mengetahui dan dapat menerapkan pengetahuan tentang makna angka yang ditunjukkan oleh jarum jam sebagai penunjuk waktu dalam menjalani rutinitas sehari-hari.

Sedangkan pada siklus ke dua, anak diarahkan untuk memahami fungsi jam dan konsep waktu terkait dengan kemampuan mengontrol lamanya suatu kegiatan dilakukan. Kegiatan ini bertujuan agar tidak berlarut-larut dalam penyelesaiannya maka anak perlu dikenalkan pada istilah menit dalam jam. Sedangkan sebagai alat kontrolnya, anak dikenalkan pada alarm. Alarm menit yang disetel menggunakan gadget (HP) karena jam weker biasa tidak bisa mengontrol lama waktu dalam menit. Agar anak tidak bosan dengan cara 
klasikal tatap muka, maka dirancang kegiatan dengan membuat film tutorial pendek, cara menyetel alarm di HP. Selain itu, tujuan dari pembuatan film tutorial dengan media televisi dan penggunaan HP sebagai media pembelajaran dimaksudkan agar guru mengetahui pentingnya unsur teknologi yang sehari-hari diketahui anak. Selama ini TK Yasmin juga sudah menggunakan televise sebagai media pembelajaran untuk memutar film edukasi, namun film tersebut bukan buatan guru. Demikian juga Hp, guru sering menggunakan sebagai contoh untuk media belajar alat komunikasi, namun sebatas sebagai alat penyampai berita.

Pada Siklus 2, berdasarkan refleksi dari siklus 1, dosen dan guru menyepakati untuk lebih mengembanglatihkan kompetensi dasar menyelesaikan masalah sehari-hari secara kreatif dengan meningkatkan kemampuan anak dalam menghubungkan kegiatan dengan lama waktu pelaksanaan dan mampu mengkomunikasikan kegiatan yang dilakukan pada orang lain. Pada kegiatan di siklus 2 diharapkan selain mampu menyebutkan jam untuk kegiatan rutin yang dilakukan, anak dapat menjelaskan berapa lama kegiatan itu dilakukan. Untuk meningkatkan kemampuan tersebut, dirancang suatu kegiatan belajar yang mengenalkan anak pada proses mengidentifikasi kontrol pelaksanaan kegiatan. Kegiatan ini dirancang dengan cara mengenalkan anak pada fungsi pengatur waktu (alarm) dengan menggunakan gadget.

Perubahan setting pembelajaran juga dilakukan dari metode diskusi terbimbing dengan metode tutorial, dengan menggunakan film tutorial pendek mengenai cara mengaktifkan alat pengontrol waktu lama berkegiatan pada handphone (alarm). Perubahan metode ini dipilih agar anak tidak bosan dengan metode diskusi terbimbing, serta penggunaan teknologi diyakini akan menarik fokus perhatian anak. Setting pembelajaran juga diubah dengan membagi anak dalam kelompok kecil dengan pengawasan. Hal ini dimungkinkan terjadi karena pada siklus 2 ini masuk mahasiswa observer yang dapat berpartisipasi dalam kegiatan ini.

\section{B. Pelaksanaan}

Pada pertemuan pertama di siklus 1, peserta didik dikenalkan akan fungsi jarum jam dengan menggunakan media jam dari karton yang ada di kelas. Jarum pendek berfungsi untuk menunjukkan tepatnya jam sesuai angka sedangkan jarum panjang saya sebut sebagai jarum penunjuk menit. Kata “jam.. " ditunjukkan oleh jarum pendek yang menunjuk pada angka terntentu dan jarum panjang menunjuk pada angka 12. Konsep waktu yang pertama dikenalkan adalah menyebutkan kegiatan rutin anak. Anak-anak diberi kesempatan untuk menunjukkan angka pada jam untuk kegiatan rutin yang menunjuk pada waktu bangun tidur, waktu berangkat sekolah, waktu pulang 
sekolah dan waktu tidur. Sebagian besar anak sudah menunjuk pada angka yang benar ketika diminta menunjukkan angka jam tertentu yang mewakili waktu tertentu. Namun anak belum memahami bahwa jam yang sama dapat berarti waktu yang berbeda. Sehingga anak menyatakan tidur pada jam 25, bangun jam 1 malam sesudah mendapat penjelasan bahwa angka yang sama dapat berarti pagi atau tengah malam.

Diperkenalkan pula satuan menit sebagai pengukuran lama kegiatan dilakukan. Waktu berkegiatan yang pendek diberi batasan tidak lebih dari 10 menit. Sedangkan perpanjangan waktu berkegiatan dibatasi 5 menit. Lebih dari 15 menit disebut sebagai waktu yang lama. Kegiatan ini mampu mendapat perhatian anak. Anak-anak terlibat berkegiatan hingga selesai.

Secara umum anak sudah memiliki pengetahuan tentang bilangan yang ada pada jam dari angka $1-12$. Sebagian besar sudah dapat menyebutkan angka dengan tepat, posisi jarum dengan benar meski masih dengan arahan dari pendidik saat menggambarkan posisi jarum untuk waktu yang diminta atau yang dipilih anak. Namun anak- anak masih mengalami kesulitan untuk mengetahui tentang mengontrol lama waktu pelaksanaan kegiatan. Disepakati dengan kolaborator untuk menunda konstrak pengetahuan tentang lama pelaksanaan suatu kegiatan dilakukan.

Pada pertemuan ketiga sebagai pertemuan terakhir siklus 1 anak-anak di kelompok Merapi diuji pengetahuannya tentang fungsi jam dan hubungan konsep jam dengan konsep waktu. Sebagian besar anak telah mengenal dan dapat menyebutkan lambang bilangan berupa angka-angka pada jam. Anak-anak juga dapat menyebutkan konsep waktu untuk kegiatan yang mereka lakukan seharihari seperti waktu bangun tidur yang dilanjut atau tidak sholat subuh, menyebutkan jam main atau nonton tv sesudah waktu maghrib. Setiap anak antusias menyampaikan jam tidur maupun jam bangun atau jam berangkat sekolah. Selanjutnya kegiatan mengingat kembali fungsi jarum jam dengan menggunakan media jam dari karton yang ada di kelas. Menanyakan kapan waktu-waktu rutin anak dan meminta beberapa anak memeragakan cara menunjukkan posisi jarum jam pada waktu yang disebut.

Kegiatan berikutnya, dosen menunjukkan gambar dummy jam yang sudah diberi angka namun tanpa jarum. Kegiatan ini bertujuan untuk mengukur kemampuan anak dalam menunjukkan hubungan kegiatan rutinnya dengan pengetahuan akan fungsi jarum jam untuk menunjukkan waktu yang dimaksud. Anak-anak diminta untuk menuliskan angka pada titik yang menjadi tempat angka tertentu. Sebagian besar anak sudah mampu menulis, meski sebagian kecil anak masih menulis terbalik angka-angka tertentu.

Pada siklus 2, sesuai dengan tujuan perbaikan kemampuan dasar anak dalam memahami konsep waktu, maka salah satu perubahan adalah pada metode yang digunakan dalam proses 
pembelajaran. Agar anak tetap fokus untuk belajar tentang materi yang sama dirancang perubahan metode pembelajaran dari diskusi terbimbing dengan metode tutorial terfokus, yaitu elaborasi metode tutorial melalui media televisinyang dilanjut dengan kegiatan penugasan dengan pendampingan. Kegiatan ini merupakan upaya memasukkan teknologi pada proses belajar anak. Pada saat menonton, anak dibagi dalam kelompok kecil dengan pendampingan agar kegiatan tetap kondusif dengan bantuan guru mitra dan mahasiswa observer. Kegiatan kooperatif ini perlu dilakukan agar anak dapat melaksanakan kegiatan yang diajarkan melalui film tutorial yang telah ditonton bersama. Kegiatan diawali dengan menonton film tutorial di televisi kemudian dilanjut dengan mengerjakan LKPD tetap dalam kelompok kecil dan dengan pengawasan dan dikontrol oleh alat pengatur waktu lama berkegiatan (alarm) pada HP. Alarm diatur dengan kesepakatan bersama anak-anak untuk berapa lama mereka akan mengerjakan LKPD. Anak-anak antusias menyepakati waktu lima belas menit untuk mengerjakan tugas. Mengapa perlu waktu yang lama, saat ditanyakan demikian, anak-anak sebagian besar menjawab mereka ingin mewarnai, menggambar atau berpikir untuk menjawab pertanyaan dalam LKPD.

\section{Pengamatan}

Secara umum dapat dikatakan pembelajaran pada hari-hari pertama siklus 1 belum kondusif. dikarenakan anak yang setelah berkegiatan tidak fokus pada kelanjutan kegiatan yang dilakukan oleh temannya. Meski anak antusias untuk mencoba memutar jam atau menggambarkan jarum jam dan mengisi angka pada jam untuk menunjukkan waktu yang diminta, namun setelah usai berkegiatan sebagian anak sibuk bermain-main sendiri atau bermain dengan temannya. Masih ada anak belum berani menyampaikan pengetahuannya tentang jam dan waktu yang berkaitan dengan kegiatan rutin yang dilakukan anak.

Keadaan berubah saat pertemuan terakhir di siklus 1 pembelajaran berjalan kondusif. Anak- anak antusias untuk mencoba memutar jam untuk menunjukkan waktu yang diminta. Pada saat kegiatan menggambar jarum jam, anak-anak menunjukkan sikap ingin tahu dan ingin mencoba. Beberapa anak masih belum tepat dalam menggambar jarum penunjuk angka meski dia tahu angka yang dimaksud. Ada juga anak yang mencoba menggambar posisi jarum yang tidak tepat kemudian menatap dosen. Saat ditanya apakah dia mau menggambar jam..., dosen menyebut sesuai gambar, anak mengiyakan. Yang dimaksudkan adalah anak ternyata menyebutkan jam yang tidak menunjukkan tepat jam tunggal, sesuai angka, melainkan menyebut jam dengan waktu pecahan seperti setengah delapan, jam enam kurang seperempat.

Hal ini menunjukkan anak mengetahui fungsi jarum jam dengan menyebutkan fungsi jarum pendek menunjuk pada jam tertentu yang diwakili oleh angka yang ditunjuk 
jarum pendek. Sebagian besar anak dapat menyebutkan kembali fungsi jarum panjang sebagai jarum menit untuk menunjukkan saat tepat jam tertentu dengan satuan seperti "jam... tepat" atau "jam setengah..." "Jam ..tepat" berarti jarum panjang menunjuk pada angka 12, sedangkan melalui kasus tertentu anak belajar jarum panjang di angka enam maka penyebutan waktu menjadi "jam setengah...".

Pada akhir pertemuan pertama siklus 1, meski anak dapat mengenali setiap angka pada jam, namun saat menulis angka-angka pada jam dummy anak masih menulis terbalik-balik pada beberapa angka tertentu, seperti angka $2,3,5,6,9$. Anak juga dapat mengidentifikasi waktu-waktu tertentu yang dihubungkan dengan jam seperti jam 8 masuk sekolah. Jam 11 pulang sekolah. Atau pernyataan, aku bangun jam 5 tapi aku ga sholat subuh. Pada anak yang menggambar jam tidak pada waktu tunggal, anak memiliki alasan tertentu sesuai dengan kebiasaan yang mereka lakukan. Seperti Raisha yang menyebutkan bangun jam enam kurang seperempat, beralasan agar neneknya memiliki waktu untuk mengurus Raisha terlebih dahulu, karena jam enam neneknya harus mengurus adik Raisha. Kasus yang lain ada pada Adrian yang menyebutkan bangun jam enam dan tidak mandi karena langsung berangkat ke sekolah.

Pada siklus 2 ini, anak nampak lebih fokus dalam berkegiatan, mampu menyesaikan tugas dengan kesepakatan lama waktu pengerjaan tugas yang dibatasi dengan mengatur alarm. Pengenalan alarm membentuk sikap untuk mendahulukan penyelesaian tugas. Muncul cara-cara kreatif yang dilakukan anak agar dapat menyelesaikan tugas seblum alarm berbunyi, misalnya lebih tekun dan fokus dalam pekerjaannya, bertanya tentang sisa waktu dengan kalimat "berapa menit lagi?", membagi kiat pada teman yang Nampak lambat agar melakukan tindakan sebagaimana yang dia lakukan. Seperti Fafai yang membagi kiat pada Anin agar menulis dengan lebih cepat karena waktu tinggal sedikit sebelum alarm berbunyi. Saat alarm berbunyi dan beberapa anak belum selesai tugasnya, temantemannya meminta waktu tambahan dengan menyetel alarm lagi. Dari pengalaman bekerja dengan batasan waktu, anak belajar untuk lebih disiplin dalam menyelesaikan tugas dan tidak bermain-main sebelum tugas selesai.

\section{Pembahasan}

Kompetensi dasar mengetahui cara memecahkan masalah sehari-hari dan berperilaku kreatif ditunjukkan oleh antusiasme anak untuk mencoba menunjukkan jam untuk waktu yang diminta atau dipilih sendiri oleh anak. Anak mulai dapat membedakan jam yang menunjukkan waktu untuk kegiatan sehari-hari seperti waktu masuk sekolah jam 8 pagi, waktu tidur jam 8 malam. Kedua, kompetensi dasar menyelesaikan masalah sehari-hari secara kreatif ditandai munculnya komentar kreatif seperti misalnya disampaikan oleh beberapa anak, seperti 
Arjuna yang berkata, "Aku tidur jam 11 malam dan bangun jam 1 malam. Atau Ayra yang berkata bangun pagi jam 3 karena membantu Ibu membuat kue. Kemunculan kompetensi menyelesaikan masalah sehari-hari secara kreatif ini dibuktikan dengan kemampuan anak menunjukkan posisi jarum jam untuk menyatakan waktu yang dinyatakan sebagai waktu berkegiatan tertentu.

Pada akhir siklus 1, pada kemampuan anak memecahkan masalah dan berperilaku kreatif ditunjukkan anak dengan memahami jam yang disebutkan dihubungkan dengan waktu seperti bangun jam 5 pagi. Makan pagi jam 6, tidur jam 9 malam. Atau Raisha yang menunjukkan telah menerapkan belajar tentang jam ini untuk mengetahui kebiasaan yang menjadi rutinitasnya di rumah. Raisha menjelaskan alasan mengapa dia harus bangun pukul enam kurang seperempat, karena pada pukul enam adalah giliran nenek mengurus adiknya. Atau Adrian salah seorang anak yang tinggal sebagai anak full day di TPA Yasmin, yaitu anak yang dititipkan secara penuh pada tempat penitipan anak Yasmin. Adrian menjalani rutinitas berangkat sekolah lebih pagi karena berangkat bersama ayahnya, sehingga tidak sempat mandi.

Sedangkan capaian anak pada menyelesaikan masalah secara kreatif dihubungkan dengan kemampuan anak menghubungkan lama waktu penyelesaian tugas yang menggunakan satuan menit. Dikatakan sebentar bila kegiatan itu selesai sebelum 10 menit. Sedangkan dikatakan kegiatan lama bila memakan waktu lebih dari 15 menit.
Hanya satu anak yang menyebut tentang hal ini di siklus 1, yaitu Fafai, yang menyebut bahwa dia mandi selama 15 menit dan sarapan 10 menit. Fafai merupakan anak yang nampaknya selalu mengkomunikasikan apa yang dipelajari sejak hari pertama siklus 1 pada orang tuanya, sehingga menunjukkan kemampuan lebih baik dalam memahami fungsi jam dan konsep waktu diantara teman-temannya.

Masih terdapat beberapa kelemahan pada akhir siklus 1 terutama tentang pemahaman anak akan lamanya kegiatan yang mereka lakukan. Dosen dan guru kolaborator memperbaiki perencanaan kegiatan dengan merancang penggunaan media lain untuk menjelaskan tentang konsep kontrol penggunaan waktu. Pengenalan awal dengan menggunakan satuan menit sebagai batasan lama berkegiatan tetap disepakati, dengan ketentuan mengenalkan anak pada konsep penggunaan waktu yang tidak lama dalam hitungan 10 menit. Perpanjangan waktu dikenalkan dalam batasan 5 menit. Sehingga dikatakan penggunaan waktu lebih dari 15 menit sebagai penggunaan waktu yang lama dalam berkegiatan. Kegiatan dirancang dibatasi pada kegiatan yang membutuhkan waktu pendek seperti mandi, makan, berpakaian, atau perjalanan ke sekolah.

Perubahan setting belajar dari metode diskusi terbimbing menjadi metode tutorial terfokus. Pengenalan akan batasan waktu ini bertujuan mengenalkan anak untuk lebih fokus dalam melakukan tugas dan melatih 
anak belajar meregulasi kedisiplinan diri. Anak-anak tidak merasa dalam tekanan karena pembatasan waktu dilakukan sebagai kesepakatan bersama. Anak juga belajar dan saling mendukung untuk lebih disiplin dan bertanggung jawab pada tugasnya.

Sebagian besar anak sudah memahami dan dapat menghubungkan penggunaan waktu dengan lama berkegiatan yang dinyatakan dalam hitungan menit. Sebagian besar anak dapat menunjukkan cara menyetel alarm dengan menggunakan hp untuk membatasi waktu atau sebagai penanda waktu tertentu. Hanya tersisa dua anak yang tidak ingin menceritakan waktu kegiatan yang sudah dibuat. (Aiko. Zia). Perkembangan menyolok terjadi pada beberapa anak yang di akhir siklus ini mau terlibat aktif dalam kegiatan mulai mengerjakan tugas menunjukkan waktu dalam jam, bercerita tentang kegiatan yang dilakukan dan mau terlibat dalam kegiatan bertanya jawab.

Kemampuan anak memahami masalah dan menyelesaikan secara kreatif telah ditunjukkan oleh sebagian besar anak., bahkan oleh anak yang dalam pertemuan sebelumnya cenderung mengalami masalah mengendalikan emosi. Kondisi ini terjadi pada seorang anak (Jun) yang meminta perhatian lebih. Dengan mengenalkan waktu dan penggunaan jam sebagai pengatur kegiatan, permasalahan anak tersebut lebih mudah diselesaikan. Demikian pula dengan Adrian, yang pada hari-hari lain suka bermain sendiri atau mengganggu temannya, akhirnya dapat fokus menyelesaikan tugas. Dapat dikatakan dengan mengenalkan fungsi jam dan konsep waktu, anak belajar mengendalikan diri agar dapat terlibat aktif dalam pelaksanaan kegiatan.

Secara umum Kelas Merapi merupakan kelas dengan anak-anak yang aktif, yang ketika di awal pembelajaran cenderung sulit fokus dalam kegiatan yang pendek sehingga memerlukan pengalih perhatian. Namun dengan melatih anak mengenal fungsi jam dan konsep waktu, anak belajar meregulasi pengetahuan dan sikap yang terwujud dalam bentuk keterampilan mengolah diri dan emosi. Menyajikan suatu bentuk pembelajaran dengan konten yang sama memerlukan perubahan dalam metode penyajian. Salah satu yang membantu pembelajaran adalah penggunaan media teknologi seperti televisi dan gadget.

Konsep waktu merupakan konsep abstrak yang biasanya dikenalkan pada anak secara terpisah dengan konsep pengenalan jam atau hari. Pengenalan waktu pada anak usia dini dan menghubungkan dengan fungsi jam diperlukan agar anak dapat belajar menyusun kembali pengetahuan dan sikap (regulasi diri) menjadi bentuk keterampilan tindak seperti mampu bertanggung jawab terhadap tugas, disiplin, mampu bekerja sama dan perlu pelatihan terus menerus sehingga anak memiliki konstrak pengetahuan, sikap dan tindakan yang kritis dan kreatif. Dengan demikian untuk materi pembelajaran ini sudah berhasil dilakukan. 
Kelemahan yang terjadi hingga akhir kajian adalah ada anak yang belum mampu mengkomunikasikan kegiatan yang sudah dilakukan, meskipun secara umum diketahui anak telah mampu melakukan regulasi diri memahami konsep waktu. Dengan demikian masih diperlukan upaya pendekatan pembelajaran yang berbeda dari kajian ini.

\section{SIMPULAN}

Pengenalan lambang bilangan yang ada pada jam dan konsep waktu pada anak melalui identifikasi kegiatan sehari-hari yang dilakukan anak mampu mengenalkan makna waktu dengan memahami fungsi jam secara komprehensif. Konsep waktu merupakan konsep abstrak yang dapat membantu anak berpikir kritis. Pengenalan waktu pada anak usia dini membantu menghubungkan fungsi jam dengan kegiatan mengontrol waktu berkegiatan (lama melaksanakan suatu tugas) sehingga anak dapat belajar menyusun kembali pengetahuan dan sikap (regulasi diri) menjadi bentuk keterampilan tindak seperti mampu bertanggung jawab terhadap tugas, disiplin, mampu bekerja sama. Namun perlu pelatihan terus menerus sehingga anak memiliki konstrak pengetahuan, sikap dan tindakan yang kritis dan kreatif. Dengan demikian untuk materi pembelajaran ini sudah berhasil dilakukan.

\section{Ucapan Terima Kasih}

Kegiatan penelitian ini merupakan bagian dari kegiatan Hibah Pendampingan Dosen Di Sekolah (PDS), yang merupakan rangkaian Hibah Revitalisasi Lembaga Penyelenggara Tenaga Kependidikan yang didanai oleh Direktorat Pembelajaran dan Kemahasiswaan Kementerian Riset, Teknologi dan Pendidikan Tinggi. Peneliti menyampaikan terima kasih pada Tim Pelaksana Hibah PDS tahun 2018 Universitas Muhammadiyah Jember, yang telah memberi kepercayaan untuk ikut dalam sumbangsih pengetahuan di bidang Pendidikan Anak Usia Dini.

\section{DAFTAR PUSTAKA}

Cester, I., Mioni, G., Cornoldi, C. (2017). Time processing in children with mathematical difficulties. Learning and Individual Differences 58 $\underline{22-30}$

Charlesworth, R dan Lind, K.K. (1990). Math and Science For Young Children. Delmar Publisher Inc. ${ }^{\circledR}$

Congdon. E.L., Kwon, MK., Levine,S.C., (2018). Learning to measure through action and gesture: Children's prior knowledge matters. Cognition 180. $\underline{182-190}$

Hatch, A. (2007). Early Childhood Qualitative Research. Taylor and Francis Group. 
Wahju Dyah Laksmi Wardhani, Dewi Khoirotus Sadiyah. KONSTRUKSI BERFIKIR KRITIS MELALUI PENGENALAN FUNGSI JAM DAN KONSEP WAKTU PADA ANAK USIA DINI. Early Childhood Vol. 2 No. 2a, November 2018

Hildebrand, V. (1996). Introduction to Early Childhood Education. Macmillan Publishing Company.

Oliemat, E., Ihmeideh, F., AlKhawaldeh, M., (2018). The use of touch-screen tablets in early childhood: Children's knowledge, skills, and attitudes towards tablet technology. Children and Youth Services Review. doi:10.1016/j.childyouth.20 $\underline{18.03 .028}$

Volk, M., Coti, M., Zajc, M., Starci, A.I., (2017)Tablet-based cross-curricular maths vs. traditional maths classroom practice for higher-order learning outcomes. Computers \& Education 114. $1 \mathrm{e} 23$

Zhang, M., Hudson, J.A., (2018). Children's understanding of yesterday and tomorrow. Journal of Experimental Child Psychology 170. 107$\underline{133}$ 